Article

\title{
Iron(II) Spin Crossover (SCO) Materials Based on Dipyridyl-N-Alkylamine
}

\author{
Taous Houari ${ }^{1,2}{ }^{\text {Emmelyne Cuza }}{ }^{1}$, Dawid Pinkowicz ${ }^{3}{ }^{\circledR}$, Mathieu Marchivie $\left.{ }^{4}{ }^{(}\right)$, Said Yefsah ${ }^{2}$ \\ and Smail Triki ${ }^{1, *(1)}$ \\ 1 Univ Brest, CNRS, CEMCA, 6 Avenue Le Gorgeu, C.S. 93837-29238 Brest CEDEX 3, France; \\ taous.houari@ummto.dz (T.H.); Emmelyne.Cuza@univ-brest.fr (E.C.) \\ 2 Faculté des Sciences, Université Mouloud Mammeri, Tizi-Ouzou 15000, Algeria; said.yefsah@ummto.dz \\ 3 Faculty of Chemistry, Jagiellonian University, Gronostajowa 2, 30-387 Kraków, Poland; \\ dawid.pinkowicz@uj.edu.pl \\ 4 CNRS, University of Bordeaux, ICMCB, UMR 5026, 87 Av. Doc. A. Schweitzer, F-33608 Pessac, France; \\ Mathieu.Marchivie@icmcb.cnrs.fr \\ * Correspondence: smail.triki@univ-brest.fr; Tel.: +33-298-016-146
}

Received: 1 October 2018; Accepted: 21 October 2018; Published: 24 October 2018

\begin{abstract}
We present here a new series of spin crossover (SCO) Fe(II) complexes based on dipyridyl- $N$-alkylamine and thiocyanate ligands, with the chemical formulae $\left[\mathrm{Fe}(\mathrm{dpea})_{2}(\mathrm{NCS})_{2}\right]$ (1) (dpea $=2,2^{\prime}$-dipyridyl-N-ethylamine), I-[Fe(dppa $\left.)_{2}(\mathrm{NCS})_{2}\right]$, (2) II-[Fe(dppa $\left.)_{2}(\mathrm{NCS})_{2}\right]$, and $\left(2^{\prime}\right)$ (dppa $=2,2^{\prime}$-dipyridyl- $N$-propylamine). The three complexes displayed nearly identical discrete molecular structures, where two chelating ligands (dpea (1) and dppa (2 and $\left.\mathbf{2}^{\prime}\right)$ ) stand in the cis-positions, and two thiocyanato-kN ligands complete the coordination sphere in the two remaining cis-positions. Magnetic studies as a function of temperature revealed the presence of a complete high-spin (HS) to low-spin (LS) transition at $T_{1 / 2}=229 \mathrm{~K}$ for 1 , while the two polymorphs $\mathrm{I}-\left[\mathrm{Fe}(\mathrm{dppa})_{2}(\mathrm{NCS})_{2}\right](2)$ and II-[Fe(dppa $\left.)_{2}(\mathrm{NCS})_{2}\right]\left(2^{\prime}\right)$ displayed similar magnetic behaviors with lower transition temperatures $\left(T_{1 / 2}=211 \mathrm{~K}\right.$ for $2 ; 212 \mathrm{~K}$ for $\left.2^{\prime}\right)$. Intermolecular contacts in the three complexes indicated the absence of any significant interaction, in agreement with the gradual SCO behaviors revealed by the magnetic data. The higher transition temperature observed for complex 1 agrees well with the more pronounced linearity of the $\mathrm{Fe}-\mathrm{N}-\mathrm{C}$ angles recently evidenced by experimental and theoretical magnetostructural studies.
\end{abstract}

Keywords: $\mathrm{Fe}(\mathrm{II})$ complex; dipyridyl-N-alkylamine ligands; high spin (HS); low spin (LS); spin cross-over (SCO); magnetic transition

\section{Introduction}

The design of new coordination materials exhibiting the spin crossover (SCO) behavior is one of the most relevant challenge in the field of switchable materials [1-15]. In such materials, the spin state can be switched from a high-spin (HS) to a low-spin (LS) configuration through a number of external stimuli such as temperature, pressure, magnetic field, or light irradiation, for complexes involving transition metal ions of $d^{4}-d^{7}$ electronic configurations [3-14]. However, iron(II)-based SCO complexes, for which the transition takes place between the paramagnetic high-spin (HS) state $\left(\mathrm{t}_{2 \mathrm{~g}}^{4} \mathrm{e}_{\mathrm{g}}^{2},{ }^{5} \mathrm{~T}_{2 \mathrm{~g}}, \mathrm{~S}=2\right)$ and the diamagnetic low-spin (LS) state $\left(\mathrm{t}_{2 \mathrm{~g}}^{6} \mathrm{e}_{\mathrm{g}}^{0},{ }^{1} \mathrm{~A}_{1 \mathrm{~g}}, \mathrm{~S}=0\right)$ are, by far, the most studied switchable molecular materials [1-14]. From the synthetic point of view, one of the relevant strategies to design original SCO systems is based on the use of appropriate polydentate rigid nitrogen-based ligands and simple anionic entities acting as terminal ligands, such as $\mathrm{NCX}\left(\mathrm{X}=\mathrm{S}, \mathrm{Se}, \mathrm{BH}_{3}\right)$ anions [16-22] or the more sophisticated ones such as cyanocarbanions exhibiting terminal or poly-bridging coordination 
modes $[4,7,23-27]$. The latter are able to tune the ligand field energy and some SCO characteristics such as the transition temperature.

In the large families of polydentate molecules, the use of the polypyridine-based ligands of different denticities, such as 2,2'-dipyridylamine (dpa) [18,19], tris(2-pyridyl)methane (tpc) [20,28,29], and tris(2-pyridylmethyl)amine (tpma [21,23,30-33], has allowed the preparation of discrete and extended coordination compounds exhibiting original SCO transitions, allowing to understand more on the SCO phenomenon, such as the origin of cooperativity, the presence of complete or incomplete transitions, and the occurrence of one-step or multi-step behaviors and photo-induced effects. In this context, we have reported, in the last few years, a new series of dinuclear $\mathrm{Fe}$ (II) complexes based on the tetradentate tmpa ligand [23] and, more recently, a dinuclear complex and a one-dimensional coordination polymer, both based on the functionalized tris(2-pyridyl)methane (tpc) tripodal ligands and displaying unusual $\mathrm{FeN}_{5} \mathrm{~S}$ coordination spheres. By experimental and theoretical magnetostructural studies, we have shown in both systems the crucial role of the linearity of the N-bound terminal thiocyanato ligand in the presence of the SCO transition. As a continuation of this research, we have pursued our investigations using the $\mathrm{N}$-functionalized 2,2'-dipyridylamine (dpa) bidentate ligands (see Scheme 1). The two first Fe(II) SCO systems based on the dpa ligands were reported by J. A. Real et al. [18,19]. The first one, $\left[\mathrm{Fe}(\mathrm{dpa})_{2}(\mathrm{NCS})_{2}\right]$, containing two cis-thiocyanato-kN ligands, showed an incomplete SCO transition at $88 \mathrm{~K}$, while the second one, $\left.\mathrm{Fe}(\mathrm{dpa})(\mathrm{NCS})_{2}\right]_{2}$ bpym (bpym $=2,2^{\prime}$-bipyrimidine, acting as bis-chelating ligand), was reported as a dinuclear Fe(II) neutral complex with a very gradual SCO behavior at $245 \mathrm{~K}$. Inspired by these observations, a few years later, S. Bonnet et al. prepared a new rigid ligand, $N$-(6-(6-(pyridin-2-ylamino)pyridin-2-yl)pyridin-2-yl)pyridin-2-amine (bapbpy, Scheme 1), composed by two directly linked dpa units, likely to induce stronger intermolecular interactions. The latter led to the new $\mathrm{Fe}(\mathrm{II})$ complex, $\left[\mathrm{Fe}(\text { bapbpy })_{2}(\mathrm{NCS})_{2}\right]$, exhibiting a two-step SCO transition with an [HS-LS-LS] intermediate phase [22].

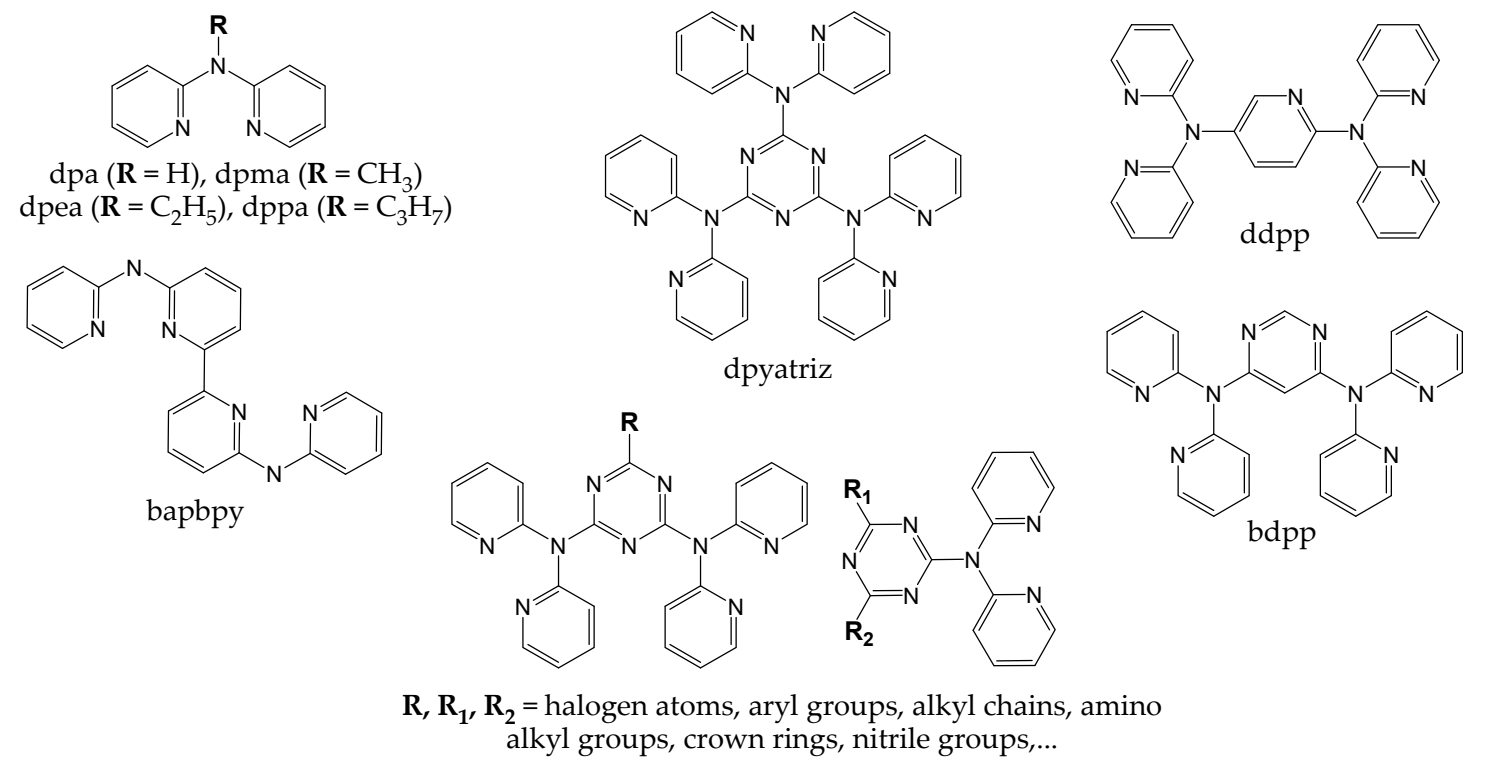

Scheme 1. Examples of ligands based on 2,2'-dipyridylamine (dpa), including those used in this work (see dpea and dppa).

With the same objectives, K.S. Murray et al. and P. Gamez et al. [34-50], separately designed triazines containing one, two, or three chelating dpa units and a variety of additional groups, such as halogen atoms, aryl groups, alkyl chains, aminoalkyl and nitriles units, as well as crown groups (see examples in Scheme 1). These sophisticated ligands have led to a variety of SCO materials exhibiting discrete structures generated by two chelating dpa units and two $\mathrm{NCX}\left(\mathrm{X}=\mathrm{S}, \mathrm{Se}, \mathrm{BH}_{3}\right)$ 
acting as cis- or trans-terminal ligands [34-42], dinuclear complexes [43-45], or 1D coordination polymers in which the $\mathrm{Fe}(\mathrm{II})$ metal ions are connected through the central triazine group containing two or three dpa units (see dpyatriz ligand and some examples of its derivatives in Scheme 1) [45-50]. Magnetic investigations revealed various magnetic behaviors ranging from incomplete and gradual transitions to abrupt complete SCO transitions. However, since such sophisticated designed ligands did not result in significantly more cooperative SCO transitions than those obtained using simple dpa or bapbpy ligands $[18,19,22]$, we have examined very recently the design of new Fe(II) SCO systems based on dpa ligands substituted by simple alkyl groups such dpma, dpea, and dppa (see Scheme 1) or by other rigid aryl functional groups such as luminophore units.

In this context, we report in the present work, the synthesis, crystal structures, and magnetic properties of a new series of spin crossover (SCO) Fe(II) complexes, based on dipyridyl- $\mathrm{N}$-alkylamine and thiocyanate ligands, with the chemical formulae $\left[\mathrm{Fe}(\mathrm{dpea})_{2}(\mathrm{NCS})_{2}\right]$ (1) $\left.\left(\text { dpea }=2,2^{\prime} \text {-dipyridyl-N-ethylamine), I-[Fe(dppa }\right)_{2}(\mathrm{NCS})_{2}\right](2), \mathrm{II}-\left[\mathrm{Fe}(\mathrm{dppa})_{2}(\mathrm{NCS})_{2}\right]$, and $\left(2^{\prime}\right)$ (dppa $=2,2^{\prime}$-dipyridyl- $N$-propylamine).

\section{Results and Discussion}

\subsection{Synthesis}

The compound 2,2'-dipyridyl- $N$-ethylamine (dpea) was prepared according to the procedure described in reference [51], while 2,2'-dipyridyl- $N$-propylamine (dppa) was prepared by using a slightly modified procedure, by replacing ethyl iodide by propyl iodide (see Figures S1-S8) [51]. The complexes, $\left[\mathrm{Fe}(\mathrm{dpea})_{2}(\mathrm{NCS})_{2}\right](\mathbf{1}), \mathrm{I}-\left[\mathrm{Fe}(\mathrm{dppa})_{2}(\mathrm{NCS})_{2}\right](\mathbf{2})$, and II-[Fe(dppa $\left.)_{2}(\mathrm{NCS})_{2}\right]\left(\mathbf{2}^{\prime}\right)$, were prepared, as single crystals, using the slow-diffusion procedure in a fine glass tube $(3.0 \mathrm{~mm}$ diameter). A solution resulting from the mixture of an aqueous solution of $\mathrm{FeCl}_{2} \cdot 4 \mathrm{H}_{2} \mathrm{O}$ and of an ethanolic solution of dpea ligand was carefully layered onto an aqueous solution of potassium thiocyanate in a 1:2:2 ratio. The infrared spectra showed a strong absorption band pointed at $2049 \mathrm{~cm}^{-1}$ for $\mathbf{1}$ and at $2057 \mathrm{~cm}^{-1}$ for $\mathbf{2}$ and 2', which can be assigned to the asymmetric stretching vibration modes $(v(\mathrm{CN}))$ of the thiocyanato- $N$ coordination modes (see Figures S9-S11).

\subsection{Crystal Structure Descriptions}

Based on the conclusions derived from the thermal variation of the magnetic data, the crystal structures of the $\left[\mathrm{Fe}(\text { dpea })_{2}(\mathrm{NCS})_{2}\right](\mathbf{1})$ complex and of the two polymorphs I-[Fe(dppa $\left.)_{2}(\mathrm{NCS})_{2}\right]$ (2) and II-[Fe(dppa $\left.)_{2}(\mathrm{NCS})_{2}\right]\left(\mathbf{2}^{\prime}\right)$ were determined at 296 and $170 \mathrm{~K}$. Complexes 1, 2, and 2' crystallized in the $P n a 2_{1}, P c c n$, and space $P \overline{1}$ space groups, respectively. The pertinent crystallographic data and selected bond lengths and bond angles for the three complexes are depicted in Table S1 and Table 1, respectively. The unit cell parameters of each complex (Table S1) revealed that there was no structural phase transition within the studied temperature range (170-296 K). The following structural descriptions of the molecular structures correspond to $296 \mathrm{~K}$, and the structural modifications induced by cooling up to $170 \mathrm{k}$ will be detailed in the paragraph dealing with structural and magnetic properties relationships. In Figure 1, the molecular structures of the complexes 1, 2, and 2', as well as the asymmetric units of each complex and the $\mathrm{FeN}_{6}$ coordination environment of the iron (II) ions are depicted. Complexes $\mathbf{1}$ and $\mathbf{2}^{\prime}$ display a similar asymmetric unit consisting of an iron metal ion, two 2,2'-dipyridyl- $N$-alkylamine molecules (dpea for $\mathbf{1}$ and dppa for $\mathbf{2}^{\prime}$ ), and two thiocyanate anions, while compound 2 exhibits an asymmetric unit involving one Fe(II) ion located on a special position, and a thiocyanate anion and a dppa molecule located on general positions. The molecular structures of the three complexes consist of discrete $\left[\mathrm{FeL}_{2}(\mathrm{NCS})_{2}\right]\left(\mathrm{L}=\right.$ dpea (1), dppa (2 and $\left.\mathbf{2}^{\prime}\right)$ neutral units, where two chelating ligands (dpea (1), dppa $\left(\mathbf{2}\right.$ and $\left.\mathbf{2}^{\prime}\right)$ ) stand in the cis-positions, and two $\mathrm{NCS}^{-}$anions, acting as thiocyanato- $\mathrm{kN}$ ligands, complete the coordination sphere in the two remaining cis-positions (Figure 1). In each complex, the iron(II) metal ion exhibits a distorted $\mathrm{FeN}_{6}$ polyhedron, arising from the coordination of the four pyridine nitrogen atoms $\left(\mathrm{N} 3, \mathrm{~N} 4, \mathrm{~N} 5, \mathrm{~N} 6\right.$ for 1 and $\mathbf{2}^{\prime}$; N3, N4, N3 ${ }^{(\mathrm{a})}$, 
$\mathrm{N} 4^{(\text {a) }}$ for 2) of the two 2,2'-dipyridyl- $N$-alkylamine chelating ligands and from the two nitrogen atoms (N1 and $\mathrm{N} 2$ for $\mathbf{1}$ and $\mathbf{2}^{\prime} ; \mathrm{N} 1, \mathrm{N1}^{(\mathrm{a})}$ for 2 ) belonging to the two terminal thiocyanato- $\mathrm{kN}$ ligands. At room temperature (296 K), the four Fe-Npyr distances in the 2.151-2.204 $\AA$ range, are longer than the Fe-N distances corresponding to the terminal thiocyanato-kN ligands (2.102-2.150 $\AA$ ), as observed in other $\mathrm{Fe}(\mathrm{II})$ complexes involving rigid pyridine-based ligands and terminal thiocyanato-kN groups $[20,28,29]$. The bond angles, depicted in Table 1, deviate considerably from the ideal values $\left(80.05^{\circ}\right.$ to $\left.95.22^{\circ}\right)$, as demonstrated by the high values of the $\Sigma$ distortion parameter [52] $\left(\Sigma=45.80^{\circ}\right.$ for $1,41.08^{\circ}$ for 2 and $39.87^{\circ}$ for $2^{\prime}$ ) summarized in Table 1.

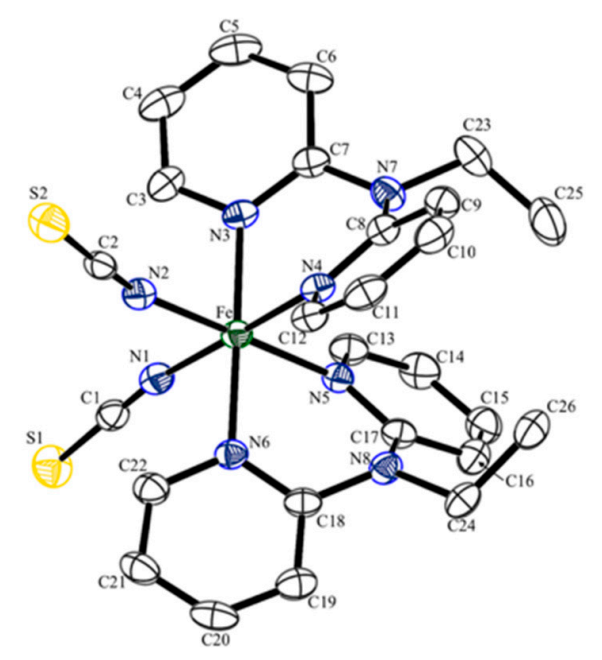

Complex 1

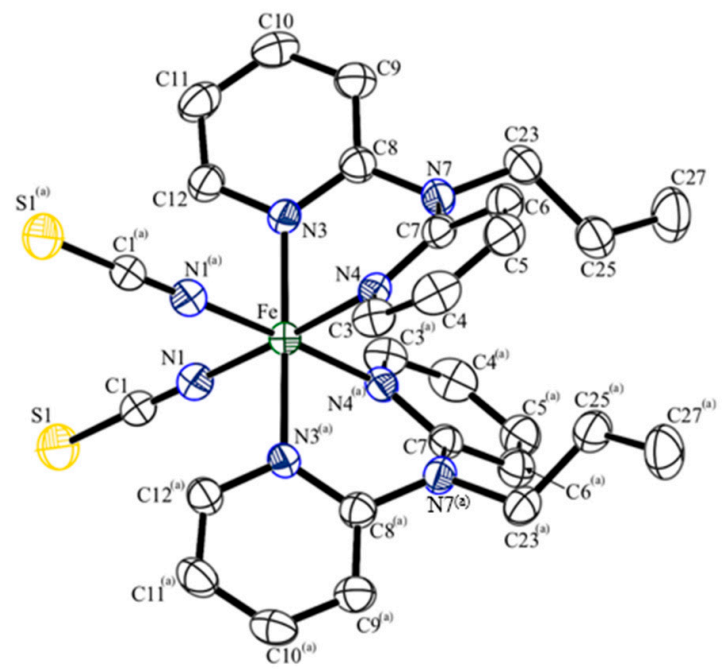

Polymorph I (2)

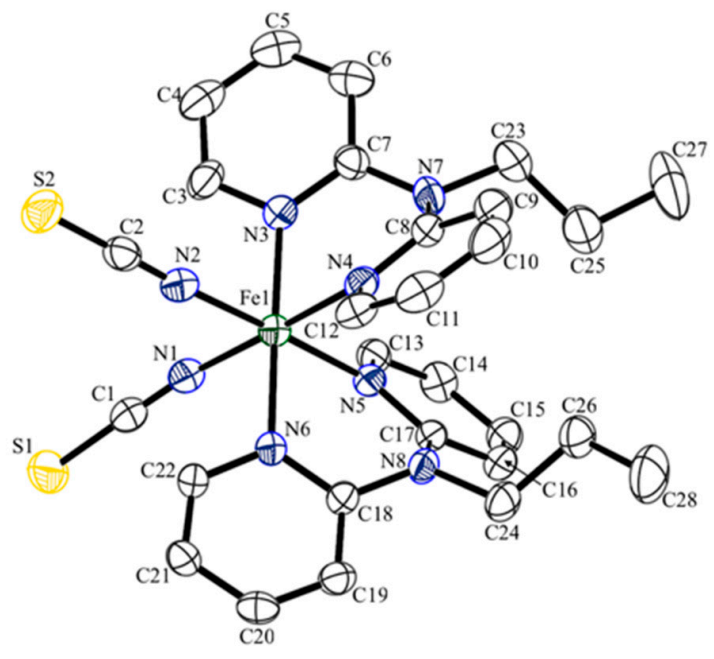

Polymorph II (2')

Figure 1. ORTEP drawings (50\% probability ellipsoids) [53], showing the molecular structures at $170 \mathrm{~K}$, the atom labelling schemes, and the coordination environments of the iron (II) ions for the three discrete complexes ( $\mathbf{1}$ and the polymorphs 2 and $\mathbf{2}^{\prime}$ ). Codes of equivalent position: (a) $1 / 2-x, 1 / 2-y, z$. 
Table 1. Selected bond lengths $(\AA)$ and bond angles $\left(^{\circ}\right)$ and the $\Sigma$ distortion parameters for the complexes 1, 2, and $\mathbf{2}^{\prime}$.

\begin{tabular}{|c|c|c|c|c|c|c|c|}
\hline \multirow{2}{*}{$\frac{\text { Complex }}{\mathrm{T} / \mathrm{K}}$} & \multicolumn{2}{|c|}{1} & \multicolumn{2}{|c|}{$2^{\prime}$} & & \multicolumn{2}{|c|}{2} \\
\hline & 296 & 170 & 296 & 170 & & 296 & 170 \\
\hline $\mathrm{Fe}-\mathrm{N} 1$ & $2.150(5)$ & $1.971(3)$ & $2.123(4)$ & $2.005(3)$ & $\mathrm{Fe}-\mathrm{N} 1$ & $2.137(3)$ & $1.968(2)$ \\
\hline $\mathrm{Fe}-\mathrm{N} 2$ & $2.102(4)$ & $1.968(3)$ & $2.111(4)$ & $2.004(3)$ & $\mathrm{Fe}-\mathrm{N} 1{ }^{(a)}$ & $2.137(3)$ & $1.968(2)$ \\
\hline $\mathrm{Fe}-\mathrm{N} 3$ & $2.151(5)$ & $1.983(3)$ & $2.175(3)$ & $2.032(3)$ & $\mathrm{Fe}-\mathrm{N} 3$ & $2.184(3)$ & $1.990(2)$ \\
\hline $\mathrm{Fe}-\mathrm{N} 4$ & $2.198(4)$ & $1.986(3)$ & $2.184(3)$ & $2.017(3)$ & $\mathrm{Fe}-\mathrm{N} 4$ & $2.204(2)$ & $1.989(2)$ \\
\hline $\mathrm{Fe}-\mathrm{N} 5$ & $2.179(4)$ & $1.976(2)$ & $2.174(3)$ & $2.019(3)$ & $\mathrm{Fe}-\mathrm{N} 4{ }^{(a)}$ & $2.204(2)$ & $1.989(2)$ \\
\hline $\mathrm{Fe}-\mathrm{N} 6$ & $2.162(4)$ & $1.978(3)$ & $2.163(3)$ & $2.034(3)$ & $\mathrm{Fe}-\mathrm{N} 3{ }^{(\mathrm{a})}$ & $2.184(3)$ & $1.990(2)$ \\
\hline$<\mathrm{d}_{(\mathrm{Fe}-\mathrm{N})}>$ & $2.157(5)$ & $1.977(3)$ & $2.155(4)$ & $2.018(3)$ & $<\mathrm{d}_{(\mathrm{Fe}-\mathrm{N})}>$ & $2.175(3)$ & $1.982(2)$ \\
\hline $\mathrm{Fe}-\mathrm{N} 1-\mathrm{C} 1$ & $164.7(5)$ & 171.5(3) & 171.6(3) & 162.2(3) & Fe-N1-C1 & $174.8(3)$ & $174.9(2)$ \\
\hline $\mathrm{Fe}-\mathrm{N} 2-\mathrm{C} 2$ & $150.7(4)$ & $161.6(2)$ & $155.6(4)$ & 174.2(3) & $\mathrm{Fe}-\mathrm{N} 1^{(\mathrm{a})}-\mathrm{C} 1^{(\mathrm{a})}$ & $174.8(3)$ & $174.9(2)$ \\
\hline N1-Fe-N2 & $94.10(17)$ & 93.36(11) & $90.98(15)$ & $89.70(12)$ & N1-Fe-N1 (a) & 91.21(17) & $90.15(12)$ \\
\hline $\mathrm{N} 1-\mathrm{Fe}-\mathrm{N} 3$ & $94.29(18)$ & $92.50(11)$ & $93.75(12)$ & 93.52(11) & $\mathrm{N} 1-\mathrm{Fe}-\mathrm{N} 3$ & $92.75(11)$ & $91.65(8)$ \\
\hline N1-Fe-N5 & 89.94(15) & $89.07(10)$ & $89.69(13)$ & $90.02(11)$ & $\mathrm{N} 1-\mathrm{Fe}-\mathrm{N} 4{ }^{(a)}$ & $89.63(11)$ & $89.44(8)$ \\
\hline N1-Fe-N6 & $89.42(17)$ & $86.98(11)$ & $90.37(12)$ & $87.23(11)$ & $\mathrm{N} 1-\mathrm{Fe}-\mathrm{N} 3^{(a)}$ & $91.74(11)$ & $87.92(8)$ \\
\hline N2-Fe-N3 & $92.31(17)$ & $88.22(11)$ & $90.28(13)$ & $88.16(11)$ & $\mathrm{N} 1^{(\mathrm{a})}-\mathrm{Fe}-\mathrm{N} 3$ & $91.74(11)$ & $87.92(8)$ \\
\hline $\mathrm{N} 2-\mathrm{Fe}-\mathrm{N} 4$ & $87.28(16)$ & $86.98(11)$ & $90.26(13)$ & $89.40(11)$ & $\mathrm{N} 1^{(\mathrm{a})}-\mathrm{Fe}-\mathrm{N} 4$ & $89.63(11)$ & $89.44(8)$ \\
\hline N2-Fe-N6 & 93.07(17) & $91.23(11)$ & $94.85(13)$ & $92.33(11)$ & $\mathrm{N} 1^{(\mathrm{a})}-\mathrm{Fe}-\mathrm{N} 3^{(\mathrm{a})}$ & $92.76(11)$ & $91.65(8)$ \\
\hline N3-Fe-N4 & 81.24(17) & $86.42(11)$ & $80.52(11)$ & 85.91(11) & N3-Fe-N4 & $80.27(9)$ & $86.21(7)$ \\
\hline N3-Fe-N5 & $94.29(17)$ & $93.83(11)$ & $94.36(12)$ & $93.73(10)$ & N3-Fe-N4 ${ }^{\text {(a) }}$ & $95.15(9)$ & $94.22(7)$ \\
\hline $\mathrm{N} 4-\mathrm{Fe}-\mathrm{N} 5$ & $89.23(13)$ & $90.63(10)$ & $89.54(12)$ & 90.90(11) & N4-Fe-N4 (a) & $90.38(13)$ & $91.05(10)$ \\
\hline N4-Fe-N6 & $94.90(15)$ & $94.10(11)$ & $95.22(12)$ & 93.34(10) & N3 ${ }^{(a)}-\mathrm{Fe}-\mathrm{N} 4$ & $95.15(9)$ & $94.21(7)$ \\
\hline N5-Fe-N6 & $80.05(18)$ & $86.74(11)$ & $80.45(12)$ & $85.78(10)$ & $\mathrm{N} 3^{(\mathrm{a})}-\mathrm{Fe}-\mathrm{N} 4^{(\mathrm{a})}$ & $80.27(9)$ & $86.21(7)$ \\
\hline $\mathrm{b}_{\Sigma /{ }^{\circ}}$ & 45.80 & 31.24 & 39.87 & 27.66 & $\mathrm{~b}_{\Sigma /{ }^{\circ}}$ & 41.08 & 25.79 \\
\hline
\end{tabular}

Symmetry transformations used to generate equivalent atoms: (a) $1 / 2-x, 1 / 2-y, z .{ }^{b} \Sigma$ is the sum of the deviation from $90^{\circ}$ of the 12 cis-angles of the $\mathrm{FeN}_{6}$ octahedron [52].

Examination of the crystal packing in the three complexes did not reveal any strong intermolecular contacts. However, since the three complexes exhibit similar molecular structures, in particular the two polymorphs, a short description of the crystal packing for each compound should give the main differences between the complexes and show clearly that the two polymorphs display different crystal packing. In order to get a global view of the intermolecular interactions, Hirshfeld surface [54] was calculated for the three complexes, and the whole interaction map is displayed as fingerprints [55] in Figure 2. On fingerprints, $d_{i}$ and $d_{e}$ represent the distance to the surface of one atom respectively inside and outside the surface. Hirshfeld surfaces and fingerprints were drawn by using the crystalexplorer software [56]. In a first approximation, the fingerprints looked similar for the three complexes at room temperature. The main intermolecular interactions are thus of the same nature and consist of hydrogen-like contacts involving the sulfur atoms (corresponding to the couple $\left(\mathrm{d}_{\mathrm{i}}, \mathrm{d}_{\mathrm{e}}\right) \approx(1.7,1.1 \AA$ ) on the fingerprints). The main differences between the three complexes involve $\mathrm{H}-\mathrm{H}$ Van der Waals contacts corresponding to the broad peak at $\left(\mathrm{d}_{\mathrm{i}}, \mathrm{d}_{\mathrm{e}}\right)$ between $(1.0,1.0 \AA)$ for $\mathbf{2}^{\prime}$ to $(1.2,1.2 \AA)$ for $\mathbf{2}$ on the fingerprints; consequently, the crystal structure of $2^{\prime}$ appeared slightly more compact than the others. At low temperature, the fingerprints looked very similar to the corresponding ones at room temperature but with lower $\left(\mathrm{d}_{\mathrm{i}}, \mathrm{d}_{\mathrm{e}}\right)$ couples. 


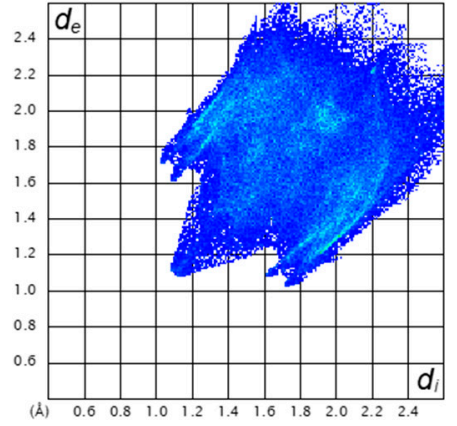

(a)

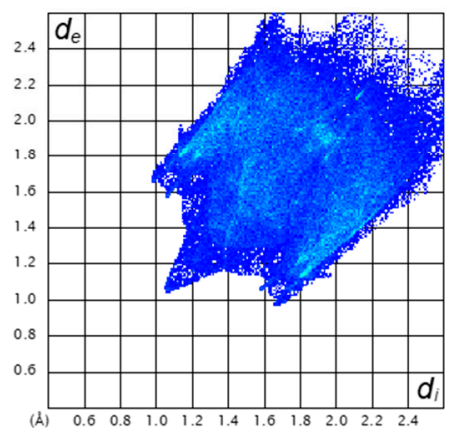

(d)

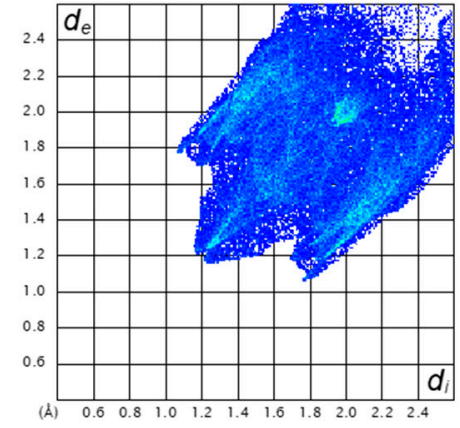

(b)

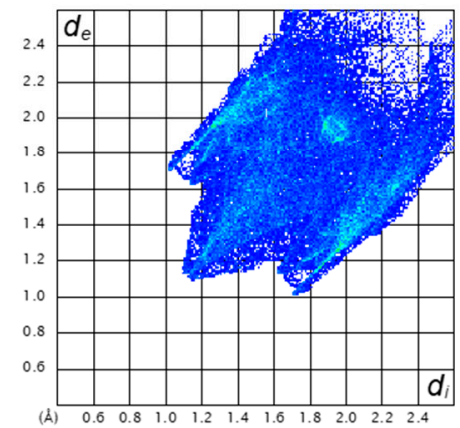

(e)

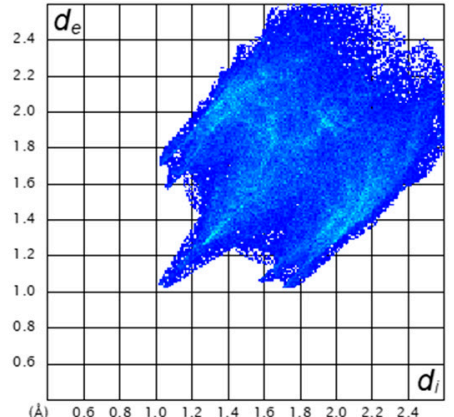

(c)

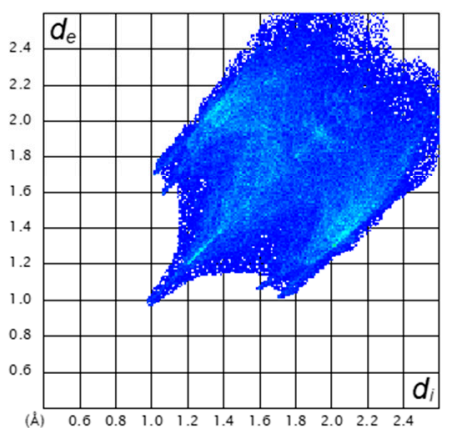

(f)

Figure 2. Fingerprints [55] of the intermolecular interactions for (a) 1, (b) 2, and (c) 2' at room temperature (296 K) and for (d) 1, (e) 2, and (f) 2' at $170 \mathrm{~K}$ (see text for definitions).

Thus, the intermolecular interactions are of the same nature but slightly shorter because of thermal contraction. This confirmed the absence of a structural transition associated to SCO for the three complexes. The main S . . H interactions were found in the three complexes between one sulfur atom and one aromatic hydrogen from the pyridine moiety in meta position to the $\mathrm{N}$ atom (corresponding to $\mathrm{H} 6$ and $\mathrm{H} 19$ for $\mathbf{1}$ and $\mathbf{2}^{\prime}$, and to H9 for 2). According to the intermolecular $\mathrm{S} \cdots \mathrm{H}$ distances (Table 2), which ranged between 2.873 and $3.105 \AA$, these interactions are weak comparing to those found in others SCO compound containing the NCS anion, such as in the [Fe(PM-L $\left.)_{2}(\mathrm{NCS})_{2}\right]$ series [52,57]. All these complexes should thus show a relatively low cooperativity, explaining the gradual spin conversions revealed by the magnetic data.

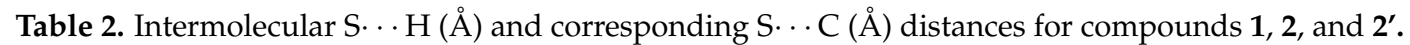

\begin{tabular}{|c|c|c|c|c|c|c|}
\hline & \multicolumn{2}{|c|}{ Compound 1} & \multicolumn{2}{|c|}{ Compound 2} & \multicolumn{2}{|c|}{ Compound $2^{\prime}$} \\
\hline & $\mathrm{d}(\mathrm{S} \cdots \mathrm{C})$ & $d(S \cdots H)$ & $\mathrm{d}(\mathrm{S} \cdots \mathrm{C})$ & $\mathrm{d}(\mathrm{S} \cdots \mathrm{H})$ & $d(S \cdots C)$ & $\mathrm{d}(\mathrm{S} \cdots \mathrm{H})$ \\
\hline $\mathrm{S} 1 \cdots \mathrm{H} 6-\mathrm{C6}^{(\mathrm{i})}$ & 3.755 & 2.999 & 3.769 & 3.105 & & \\
\hline 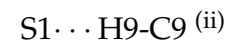 & 3.692 & 3.037 & 3.811 & 2.970 & 3.782 & 2.898 \\
\hline S2 ․ H6-C6 ${ }^{(\mathrm{iii})}$ & & & & & 3.803 & 2.886 \\
\hline $\mathrm{S} 2 \cdots \mathrm{H} 10-\mathrm{C} 10^{\text {(iv) }}$ & & & & & 3.677 & 3.028 \\
\hline $\mathrm{S} 2 \cdots \mathrm{H} 19-\mathrm{C} 19^{(\mathrm{V})}$ & 3.702 & 2.873 & & & & \\
\hline
\end{tabular}

Symmetry codes: (i) $-3 / 2-x, 1 / 2+y,-1 / 2+z$ for $1 ; 1 / 2-x, y, 1 / 2+z$ for 2 ; (ii) $1 / 2+x,-1 / 2-y, z$ for $1 ;-1 / 2$ $+\mathrm{x},-1 / 2+\mathrm{y}, 1-\mathrm{z}$ for $2 ; 1-\mathrm{x}, 1-\mathrm{y}, 1-\mathrm{z}$ for $2^{\prime}$; ${ }^{\text {(iii) }} 1-\mathrm{x}, 1-\mathrm{y},-\mathrm{z}{ }^{\text {; (iv) }} 1+\mathrm{x},-1+\mathrm{y}, \mathrm{z}$ ( $^{\text {(v) }}-3 / 2-\mathrm{x},-1 / 2+\mathrm{y}$, $1 / 2+\mathrm{z}$

\subsection{Magnetic Properties}

The susceptibility measurements were performed at $0.1 \mathrm{~T}$ magnetic field at variable temperatures in the $2-300$ or $2-350 \mathrm{~K}$ range for the three complexes. The thermal dependences of the products of 
the molar magnetic susceptibility and the temperature $(\chi m T)$ are shown in Figure 3 for complex $\mathbf{1}$ and in Figure 4 for the two polymorph complexes ( 2 and $\left.\mathbf{2}^{\prime}\right)$. For compound $\mathbf{1}$, the $\chi m T$ product of $3.205 \mathrm{~cm}^{3} \cdot \mathrm{K} \cdot \mathrm{mol}^{-1}$ at $300 \mathrm{~K}$, slightly higher than the spin only value calculated for an isolated metal ion with $S=2\left(3.0 \mathrm{emu} \cdot \mathrm{K} \cdot \mathrm{mol}^{-1}\right)$, agrees well with the expected value for a magnetically isolated $\mathrm{Fe}(\mathrm{II})$ ion in the HS state $(S=2)$ (Figure 3) [17-20]. Upon cooling, the $\chi m T$ value decreased gradually until approximately $250 \mathrm{~K}$ and then sharply decreased, reaching a value of $0.024 \mathrm{~cm}^{3} \cdot \mathrm{K} \cdot \mathrm{mol}^{-1}$ at $2 \mathrm{~K}$, indicating the presence of a complete and gradual HS to LS transition at $T_{1 / 2}=229 \mathrm{~K}$, as also revealed by the thermoschromism (yellow at $296 \mathrm{~K}$ and red at $150 \mathrm{~K}$ ) observed on single crystals (see Figure 3). For the two polymorph complexes I-[Fe(dppa $\left.)_{2}(\mathrm{NCS})_{2}\right](2)$ and II-[Fe(dppa $\left.)_{2}(\mathrm{NCS})_{2}\right]\left(2^{\prime}\right)$, the thermal variation of the $\chi m T$ products depicted in Figure 4, showed clearly that the two polymorphs exhibited similar magnetic behaviors. For the polymorph 2 , the $\chi m T$ value at $300 \mathrm{~K}\left(3.377 \mathrm{~cm}^{3} \cdot \mathrm{K} \cdot \mathrm{mol}^{-1}\right)$ was slightly lower than the corresponding value observed for the polymorph $2^{\prime}\left(3.462 \mathrm{~cm}^{3} \cdot \mathrm{K} \cdot \mathrm{mol}^{-1}\right)$.

However, in both cases, these values are in agreement with the expected value for a magnetically isolated Fe(II) ion in the HS state [17-20] with $g$ factors of 2.12 and 2.15, respectively. Upon cooling, the $\chi m T$ value decreased gradually, in both cases, until approximately $260 \mathrm{~K}$ and then sharply decreased reaching a value of $0.02 \mathrm{~cm}^{3} \cdot \mathrm{K} \cdot \mathrm{mol}^{-1}$ at $2 \mathrm{~K}$, indicating the presence of a complete and gradual HS to LS transition which was accompanied, as expected, by a change of color observed for each single crystal (See Figure 4: orange to red for 2, yellow to red for $\mathbf{2}^{\prime}$ ). The two magnetic behaviors were similar and agree well with the presence of complete spin cross-over transitions at almost similar transition temperatures $\left(T_{1 / 2}=211 \mathrm{~K}\right.$ for $2 ; 212 \mathrm{~K}$ for $\left.2^{\prime}\right)$. For the three complexes, the magnetic properties were measured in both cooling and warming modes, but no hysteretic effects were detected.

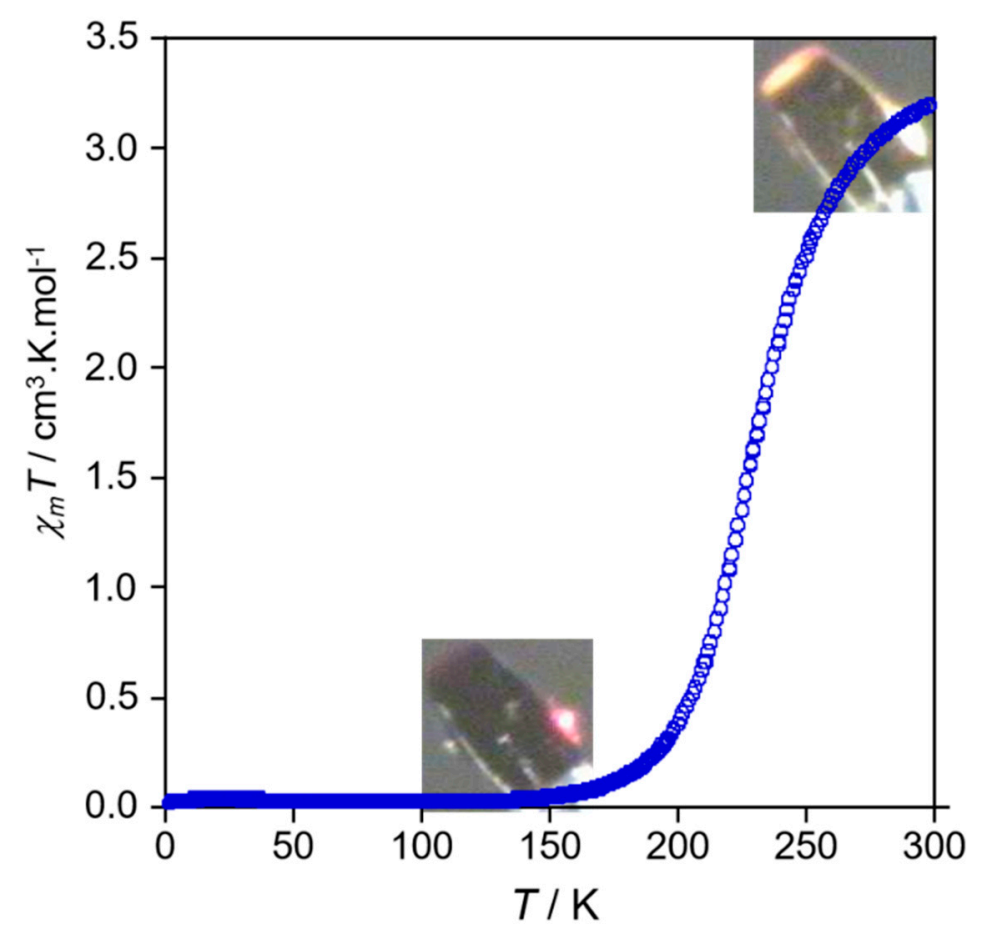

Figure 3. Thermal variation of the $\chi m T$ product for complex $\left[\mathrm{Fe}(\mathrm{dpea})_{2}(\mathrm{NCS})_{2}\right](\mathbf{1})$. 


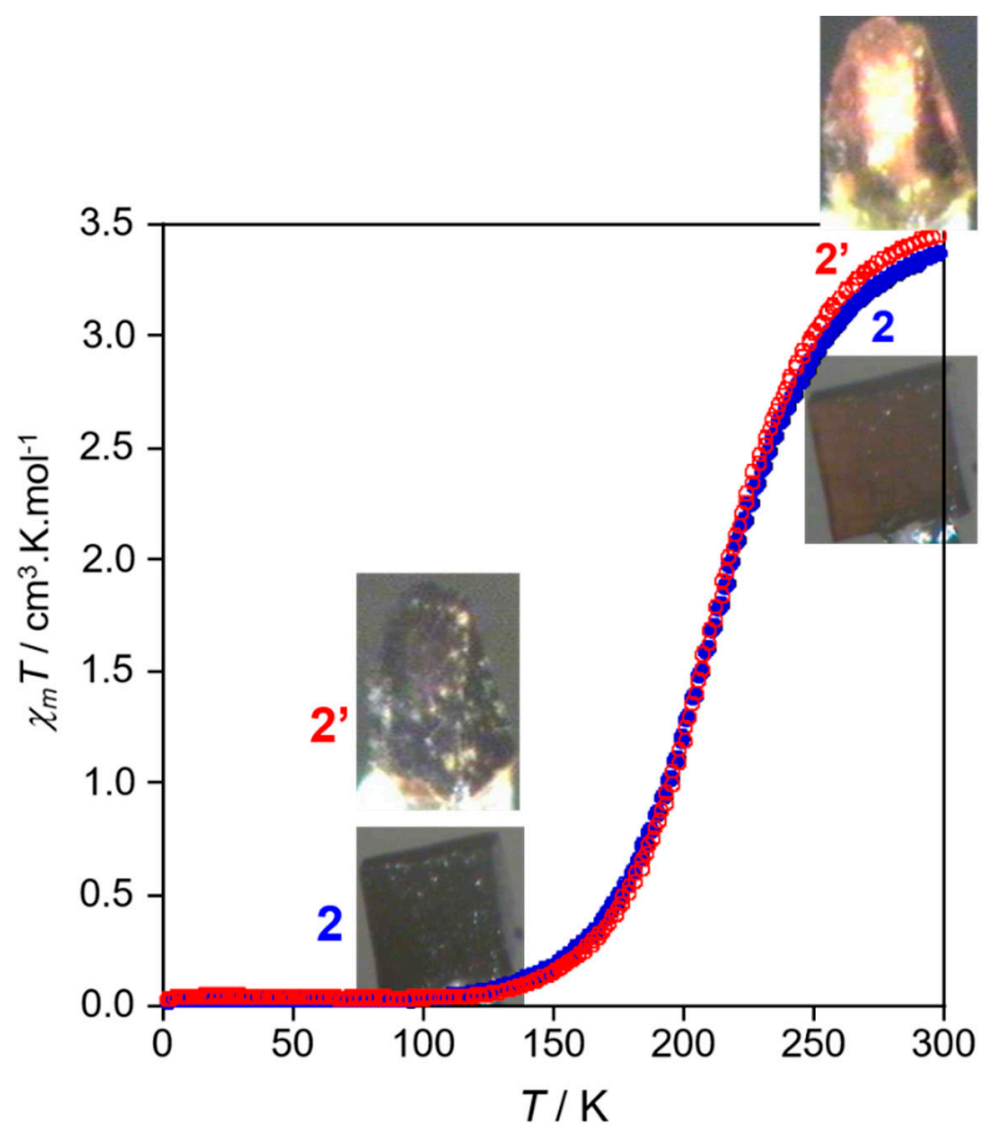

Figure 4. Thermal variation of the $\chi^{m T}$ product for the two polymorph complexes I-[Fe(dppa $\left.)_{2}(\mathrm{NCS})_{2}\right]$ (2) and II-[Fe(dppa $\left.)_{2}(\mathrm{NCS})_{2}\right]\left(2^{\prime}\right)$.

\subsection{Magneto-Structural Relationships}

On the basis of the transition temperatures derived from the magnetic studies above, the crystal structures of $\mathbf{1}, \mathbf{2}$, and $\mathbf{2}^{\prime}$ were determined at $170 \mathrm{~K}$. Since the average value of the $\mathrm{Fe}-\mathrm{L}$ distances $(\mathrm{Fe}-\mathrm{N})$ and the distortion parameter $(\Sigma)$ are highly sensitive to the $\mathrm{Fe}(\mathrm{II})$ spin state, these structural parameters will be used in this section to assign the spin state on the Fe(II) centers. Table 1 lists the temperature evolution of the $\mathrm{Fe}-\mathrm{N}$ bond lengths and selected bond angles $(\mathrm{N}-\mathrm{Fe}-\mathrm{N}$ and $\mathrm{Fe}-\mathrm{N}-\mathrm{C})$ observed for each complex, as well as the values of the $\Sigma$ distortion parameter. At room temperature $(296 \mathrm{~K})$, the average value of the six Fe-N distances $\left(<\mathrm{d}_{(\mathrm{Fe}-\mathrm{N})}\right\rangle: 2.157(5) \AA$ for 1, 2.175(3) $\AA$ for 2, and 2.155(4) $\AA$ for $2^{\prime}$ ) are in good agreement with the corresponding values observed for the HS Fe(II) ion in a $\mathrm{FeN}_{6}$ distorted octahedral environment [6,7]. As shown in Table 1, the $\mathrm{Fe}-\mathrm{N}$ bond lengths constitute the first structural parameter at the origin of the distorted $\mathrm{FeN}_{6}$ coordination spheres in the three complexes, since the four slightly different Fe-Npy distances (2.151-2.198 $\AA$ for 1, 2.184-2.204 $\AA$ for 2, and 2.163-2.184 $\AA$ for 2') are significantly longer than the two Fe-N distances corresponding to the terminal thiocyanato ligands (2.150(5) $\AA$ and 2.102(4) $\AA$ for 1, 2.137(3) $\AA$ for 2, 2.123(4) $\AA$ and 2.111(4) $\AA$ for $2^{\prime}$ ). This metric distortion is strengthened by the values of the $\mathrm{N}-\mathrm{Fe}-\mathrm{N}$ cis-bond angles (see Table 1) which deviate considerably from ideal values $\left(80.05^{\circ}\right.$ to $\left.95.22^{\circ}\right)$, as demonstrated by the relatively high values of the $\Sigma$ distortion parameter summarized in Table 1 for the three complexes, at room temperature. The crystal structures derived at $170 \mathrm{~K}$ for the three compounds revealed, as expected, significant changes since the six Fe-N distances are substantially smaller $\left(<\mathrm{d}_{(\mathrm{Fe}-\mathrm{N})}\right\rangle$ : 1.977(3) $\AA$ for 1, 1.982(2) $\AA$ for 2 and 2.018(3) $\AA$ for $2^{\prime}$ ) than the corresponding values observed for the HS state at room temperature, suggesting the presence of an LS state of the $\mathrm{Fe}(\mathrm{II})$ ion for the three complexes, as revealed by the magnetic data. However, in contrast to the crystallographic data observed at room temperature, the four Fe-Npy and the two Fe-N(NCS) distances did not show 
significant differences for the LS state (1.968-1.986 ̊̊ for 1, 1.968-1.990 for 2, and 2.004-2.034 for 2'), suggesting less distorted $\mathrm{FeN}_{6}$ environments, as demonstrated by the lower $\Sigma$ distortion parameters (Table 1). It should be noted that the evolution of the $\Sigma$ distortion parameter from the HS to the LS state $(\Delta \Sigma)$ for the three complexes was rather small $\left(14.5^{\circ}(\mathbf{1}), 15.3^{\circ}(\mathbf{2})\right.$, and $\left.12.2^{\circ}\left(2^{\prime}\right)\right)[20,52]$. This may explain the absence of any photo-induced state in the three compounds. As clearly shown by the structural characterizations, the three complexes displayed a similar discrete mononuclear structure without significant intermolecular contacts, in agreement with gradual switching behaviors, suggesting the absence of any significant cooperative effects. This observation allows to expect almost similar transition temperatures for the three complexes. Effectively, the two polymorph complexes displayed, as expected, similar transition temperatures $\left(T_{1 / 2}=211 \mathrm{~K}\right.$ for $2 ; 212 \mathrm{~K}$ for $\left.2^{\prime}\right)$, while complex 1 exhibited a SCO transition at a higher temperature $\left(T_{1 / 2}=229 \mathrm{~K}\right)$. This observation led us to examine other structural parameters within the molecular structure of the complexes, such as the Fe-N-CS bond angles. On the basis of previous experimental and theoretical magnetostructural studies in which some of us suggested that the bent N-bound terminal thiocyanato ligand promotes a weaker ligand field on the $\mathrm{Fe}(\mathrm{II})$ ion than the linear configuration [20,29], the examination of the $\mathrm{Fe}-\mathrm{N}-\mathrm{CS}$ angles, summarized in Table 1 for the three complexes, clearly showed that the linearity of the Fe-N-CS angles is more pronounced in complex 2 , exhibiting the highest transition temperature.

\section{Experimental Section}

\subsection{Materials and Instrumentation}

All the starting reagents were purchased from commercial sources (Sigma-Aldrich (Saint-Quentin Fallavier, Isère, France), Acros (Illkirch, Bas-Rhin, France)), and Alfa Aesar (Zeppelinstraße, Karlsruhe, Germany)) and used without further purification. Deuterated solvents were purchased from Sigma-Aldrich and Cambridge Isotope Laboratories. Elemental analyses were performed on a Perkin-Elmer Elemental Analyzer. Infrared (IR) spectra were collected in the range $4000-200 \mathrm{~cm}^{-1}$ on a FT-IR BRUKER ATR VERTEX70 Spectrometer. ${ }^{1} \mathrm{H}$ and ${ }^{13} \mathrm{C}$ NMR spectra were recorded on Bruker AMX-400 and AMX-75 spectrometers, and the spectra were referenced internally using residual proton solvent resonances relative to tetramethylsilane $(\delta=0 \mathrm{ppm})$. Magnetic measurements were performed with a Quantum Design MPMS3 SQUID magnetometer in the 2-350 K temperature range. Experimental susceptibility was corrected for the diamagnetism of the constituent atoms of the sample by using Pascal's tables and the diamagnetism of the sample holder.

\subsection{Syntheses of the 2,2'-Dipyridyl-N-Alkylamine Ligands}

2,2'-Dipyridyl- $N$-ethylamine (dpea) was prepared according to the procedure described in reference [51], with a yield of $1.777 \mathrm{~g}, 77 \%$. IR data $\left(\mathrm{vcm}^{-1}\right): 3068 \mathrm{w}, 3052 \mathrm{w}, 3001 \mathrm{w}, 2973 \mathrm{w}, 2929 \mathrm{w}$, $2869 \mathrm{w}, 1640 \mathrm{w}, 1582 \mathrm{~s}, 1560 \mathrm{~m}, 1466 \mathrm{~s}, 1420 \mathrm{~s}, 1320 \mathrm{~m}, 1263 \mathrm{~s}, 1137 \mathrm{~m}, 1046 \mathrm{w}, 984 \mathrm{~m}, 953 \mathrm{~m}, 922 \mathrm{w}, 769 \mathrm{~s}$, $736 \mathrm{~m}, 699$ w, 637 w, 622 w, 573 m, 533 w, 494 w, 406 w. ${ }^{1} \mathrm{H}$ NMR ( $400 \mathrm{MHz}, \mathrm{CDCl}_{3} \delta$ (ppm): $1.30(3 \mathrm{H}, \mathrm{t}$, $\left.{ }^{3} \mathrm{~J}_{\mathrm{H}-\mathrm{H}}=6.8 \mathrm{~Hz}\right) ; 4.30\left(2 \mathrm{H}, \mathrm{q},{ }^{3} \mathrm{~J}_{\mathrm{H}-\mathrm{H}}=7.2 \mathrm{~Hz}\right) ; 6.90\left(2 \mathrm{H}, \mathrm{t},{ }^{3} \mathrm{~J}_{\mathrm{H}-\mathrm{H}}=6 \mathrm{~Hz}\right) ; 7.08\left(2 \mathrm{H}, \mathrm{d},{ }^{3} \mathrm{~J}_{\mathrm{H}-\mathrm{H}}=8.4 \mathrm{~Hz}\right) ; 7.57$ $\left(2 \mathrm{H}, \mathrm{t},{ }^{3} \mathrm{~J}_{\mathrm{H}-\mathrm{H}}=7.2 \mathrm{~Hz}\right) ; 8.37\left(2 \mathrm{H}, \mathrm{d},{ }^{3} \mathrm{~J}_{\mathrm{H}-\mathrm{H}}=4.3 \mathrm{~Hz}\right) .{ }^{13} \mathrm{C} \mathrm{NMR}\left(75 \mathrm{MHz}, \mathrm{CDCl}_{3}\right) \delta(\mathrm{ppm}): 13.66\left(-\mathrm{CH}_{3}\right.$, ethyl); $43.19\left(\mathrm{~N}-\mathrm{CH}_{2}-\right.$, ethyl); $114.87(\mathrm{C}=\mathrm{C}$, aromatic); 116.94 ( $\mathrm{C}=\mathrm{C}$, aromatic); 137.20 ( $\mathrm{C}=\mathrm{C}$, aromatic); $148.44(\mathrm{~N}=\mathrm{C}$, aromatic); $157.37(\mathrm{C}=\mathrm{C}$, aromatic, quat). 2,2'-Dipyridyl-N-propylamine (dppa) was prepared using a similar procedure as reported for 2,2'-dipyridyl- $N$-ethylamine (dpea), by replacing the ethyl iodide by the propyl iodide [51]. Yield $(0.935 \mathrm{~g}, 73 \%)$. IR data $\left(\mathrm{v} / \mathrm{cm}^{-1}\right): 3420 \mathrm{br}, 3068 \mathrm{w}$, 3052 w, 3007 m, 2961 m, 2872 m, 1640 w, 1582 s, 1558 s, 1529 m, 1465 s, 1419 s, 1377 s, 1321 m, 1276 s, $1236 \mathrm{~m}, 1142 \mathrm{~m}, 1106 \mathrm{~m}, 1050 \mathrm{~m}, 985 \mathrm{f}, 957 \mathrm{~m}, 938 \mathrm{~m}, 890 \mathrm{~s}, 854 \mathrm{w}, 768 \mathrm{~s}, 735 \mathrm{~s}, 638 \mathrm{w}, 619 \mathrm{~m}, 605 \mathrm{~m}$, $578 \mathrm{~m}, 531 \mathrm{~m}, 503 \mathrm{~m}, 466 \mathrm{w}, 433 \mathrm{~m} .{ }^{1} \mathrm{H}$ NMR $\left(400 \mathrm{MHz}, \mathrm{CDCl}_{3}\right) \delta(\mathrm{ppm}): 0.96\left(3 \mathrm{H}, \mathrm{t},{ }^{3} \mathrm{~J}_{\mathrm{H}-\mathrm{H}}=7.6 \mathrm{~Hz}\right)$, $1.74\left(3 \mathrm{H}, \mathrm{q},{ }^{3} \mathrm{~J}_{\mathrm{H}-\mathrm{H}}=7.6 \mathrm{~Hz},{ }^{3} \mathrm{~J}_{\mathrm{H}-\mathrm{H}}=7.9 \mathrm{~Hz}\right) ; 4.18\left(2 \mathrm{H}, \mathrm{t},{ }^{3} \mathrm{~J}_{\mathrm{H}-\mathrm{H}}=8 \mathrm{~Hz}\right) ; 6.91\left(2 \mathrm{H}, \mathrm{t},{ }^{3} \mathrm{~J}_{\mathrm{H}-\mathrm{H}}=5.6 \mathrm{~Hz}\right) ; 7.06$ $\left(2 \mathrm{H}, \mathrm{d},{ }^{3} \mathrm{~J}_{\mathrm{H}-\mathrm{H}}=8.4 \mathrm{~Hz}\right) ; 7.58\left(2 \mathrm{H}, \mathrm{t},{ }^{3} \mathrm{~J}_{\mathrm{H}-\mathrm{H}}=7.6 \mathrm{~Hz}\right) ; 8.37\left(2 \mathrm{H}, \mathrm{d},{ }^{3} \mathrm{~J}_{\mathrm{H}-\mathrm{H}}=4.4 \mathrm{~Hz}\right) .{ }^{13} \mathrm{C} \mathrm{NMR}(75 \mathrm{MHz}$, 
$\left.\mathrm{CDCl}_{3}\right), \delta$ (ppm): $21.62\left(\mathrm{CH}_{3}-\mathrm{CH}_{2}-\right) ; 50.12\left(\mathrm{~N}-\mathrm{CH}_{2}-\right) ; 114.84$ (C=C, aromatic); 116.91 (C=C, aromatic); 137.19 ( $\mathrm{C}=\mathrm{C}$, aromatic); 148.57 ( $\mathrm{N}=\mathrm{C}$, aromatic); 157.88 ( $\mathrm{C}=\mathrm{C}$, aromatic, quat).

\subsection{Preparation of the $\mathrm{Fe}(\mathrm{II})$ Complexes $\left[\mathrm{Fe}(\text { dpea })_{2}(\mathrm{NCS})_{2}\right](\mathbf{1})$ and $\left[\mathrm{Fe}(\mathrm{dppa})_{2}(\mathrm{NCS})_{2}\right]$ Polymorphs (2 and $\left.\mathbf{2}^{\prime}\right)$}

[Fe(dpea $\left.)_{2}(\mathrm{NCS})_{2}\right]$ (1). Single crystals of $\mathbf{1}$ were prepared using a slow diffusion procedure, in a fine glass tube ( $3.0 \mathrm{~mm}$ diameter): a solution of potassium thiocyanate $(12.63 \mathrm{mg}, 0.13 \mathrm{mmol})$ in $1.0 \mathrm{~mL}$ of $\mathrm{H}_{2} \mathrm{O}$ was placed in the fine glass tube. A second solution $(2 \mathrm{~mL})$, containing a mixture of an aqueous solution $(1.0 \mathrm{~mL})$ of $\mathrm{FeCl}_{2} .4 \mathrm{H}_{2} \mathrm{O}(13 \mathrm{mg}, 0.065 \mathrm{mmol})$ and an ethanolic solution $(1.0 \mathrm{~mL})$ of dpea ligand $(25.9 \mathrm{mg}, 0.13 \mathrm{mmol})$, was then carefully added. After three days, yellow prismatic crystals of 1 were formed by slow diffusion at room temperature. $\mathrm{CHN}$ analysis: calculated for $\mathrm{C}_{26} \mathrm{H}_{26} \mathrm{FeN}_{8} \mathrm{~S}_{2}$ (1): C, 54.7; N, 19.6; H, 4.6. Found: C, 54.9; N, 19.9; H, 4.6. IR data $\left(v / \mathrm{cm}^{-1}\right): 3108 \mathrm{w}, 3079 \mathrm{w}, 3031 \mathrm{w}$, 2980 w, 2939 w, 2861 w, 2087 sh, 2049 s, 1595 s, 1573 s, 1489 w, 1461 s, 1435 s, 1335 s, 1294 m, 1233 m, $1164 \mathrm{~m}, 1073 \mathrm{~m}, 1056 \mathrm{~m}, 1012 \mathrm{~m}, 910 \mathrm{w}, 773 \mathrm{~s}, 749 \mathrm{~s}, 642 \mathrm{w}, 629 \mathrm{w}, 572 \mathrm{~m}, 507 \mathrm{~m}, 478 \mathrm{~m}, 449 \mathrm{~m}, 421 \mathrm{~s}$. [Fe(dppa $)_{2}(\mathrm{NCS})_{2}$ ] polymorphs ( 2 and $\left.2^{\prime}\right)$. Using a similar procedure as that described above for $\mathbf{1}$, but replacing dpea with dppa $(27.7 \mathrm{mg}, 0.13 \mathrm{mmol}$ ), two single-crystal phases 2 (orange prisms) and 2' (yellow prisms) formed after two weeks. $\mathrm{CHN}$ analysis: calculated for $\mathrm{C}_{26} \mathrm{H}_{26} \mathrm{FeN}_{8} \mathrm{~S}_{2}$ (2): $\mathrm{C}, 56.2 ; \mathrm{N}$, 18.7; H, 5.0. Found: C, 56.4; N, 19.1; H, 4.9. IR data $\left(\mathrm{v} / \mathrm{cm}^{-1}\right)$ polymorph I (2): $3073 \mathrm{w}, 3032 \mathrm{w}, 2974 \mathrm{w}$, 2866 w, 2086 w, 2057 s, 1638 m, 1595 m, 1489 s, 1464 m, 1455 m, 1431 s, 1344 s, 1305 m, 1278 m, 1234 m, $1167 \mathrm{~m}, 1138 \mathrm{~m}, 1112 \mathrm{w}, 1079 \mathrm{w}, 1060 \mathrm{~m}, 1032 \mathrm{~m}, 1009 \mathrm{~m}, 965 \mathrm{w}, 941 \mathrm{w}, 914 \mathrm{w}, 870 \mathrm{w}, 819 \mathrm{~s}, 786 \mathrm{~s}, 775 \mathrm{~s}$, $747 \mathrm{~m}, 643 \mathrm{~m}, 631 \mathrm{~m}, 602 \mathrm{~m}, 526 \mathrm{~m}, 505 \mathrm{~m}, 482 \mathrm{w}, 472 \mathrm{w}, 441 \mathrm{~m}, 421 \mathrm{~m}$. CHN analysis: calculated for $\mathrm{C}_{26} \mathrm{H}_{26} \mathrm{FeN}_{8} \mathrm{~S}_{2}\left(2^{\prime}\right)$ : C, 56.2; N, 18.7; H, 5.0. Found: $\mathrm{C}, 56.5 ; \mathrm{N}, 19.0 ; \mathrm{H}, 4.9$. IR data $\left(v / \mathrm{cm}^{-1}\right)$ polymorph II (2'): 3073 w, 3032 w, 2965 w, 2867 w, 2170 w, 2152 w, 2089 w, 2057 s, 1638 m, 1596 m, 1490 s, 1465 m, $1456 \mathrm{~m}, 1431 \mathrm{~s}, 1344 \mathrm{~s}, 1306 \mathrm{~m}, 1280 \mathrm{~m}, 1235 \mathrm{~m}, 1167 \mathrm{~m}, 1138 \mathrm{~m}, 1112 \mathrm{w}, 1080$ w, 1059 m, 1010 m, $964 \mathrm{w}$, 941 w, 903 w, 786 s, 775 s, 746 s, 747 m, 642 m, 631 m, 603 m, 528 m, 482 w, 472 w, 441 m, 422 m.

\subsection{X-ray Crystallography}

Crystallographic studies of compounds 1, 2 and $\mathbf{2}^{\prime}$ were performed at 296 and $170 \mathrm{~K}$. The crystallographic data were collected on an Oxford Diffraction Xcalibur CCD diffractometer with Mo $\mathrm{K} \alpha$ radiation. For data collections, except for complex $2^{\prime}$, similar single crystals were used at both temperatures: $0.20 \times 0.18 \times 0.13 \mathrm{~mm}^{3}(\mathbf{1}) ; 0.38 \times 0.30 \times 0.23 \mathrm{~mm}^{3}(\mathbf{2}) ; 0.14 \times 0.12 \times 0.10 \mathrm{~mm}^{3}$ for $\mathbf{2}^{\prime}$ at $296 \mathrm{~K}$ and $0.25 \times 0.23 \times 0.16 \mathrm{~mm}^{3}$ for $2^{\prime}$ at $170 \mathrm{~K}$. All the data collections were performed using $1^{\circ}$ $\omega$-scans with different exposure times ( $50 \mathrm{~s}$ and $40 \mathrm{~s}$ per frame for 1 at 296 and $170 \mathrm{~K}$, respectively; $10 \mathrm{~s}$ per frame for 2 at 296 and $170 \mathrm{~K} ; 50 \mathrm{~s}$ and $13 \mathrm{~s}$ per frame for $\mathbf{2}^{\prime}$ at 296 and $170 \mathrm{~K}$, respectively). The unit cell determinations and data reductions were performed using the CrysAlis program suite on the full set of data [58]. The crystal structures were solved by direct methods and successive Fourier difference syntheses with the Sir97 program [59] and refined on $F^{2}$ by weighted anisotropic full-matrix least-square methods using the SHELXL97 program [60]. All non-hydrogen atoms were refined anisotropically, while the hydrogen atoms were calculated and therefore included as isotropic fixed contributors to $F_{\mathrm{c}}$. Crystallographic data including refinement parameters, bond lengths and bond angles, are given in Table S1 and Table 1, respectively.

\section{Conclusions}

We prepared a new series of spin crossover (SCO) $\mathrm{Fe}(\mathrm{II})$ materials based on dipyridyl-N-alkylamine and thiocyanate ligands, with the chemical formulae $\left[\mathrm{Fe}(\mathrm{dpea})_{2}(\mathrm{NCS})_{2}\right]$ (1) (dpea = 2,2'-dipyridyl-N-ethylamine), I-[Fe(dppa $\left.)_{2}(\mathrm{NCS})_{2}\right](2)$, and II-[Fe(dppa) $\left.{ }_{2}(\mathrm{NCS})_{2}\right]\left(2^{\prime}\right)$ (dppa $=2,2^{\prime}$-dipyridyl- $N$-propylamine). All were structurally characterised by single-crystal $\mathrm{X}$-ray diffraction at room temperature $(296 \mathrm{~K})$ and at $170 \mathrm{~K}$ and by magnetic studies as a function of temperature. Even if they displayed different crystallographic structures, as reflected by their different crystal packing, the three Fe(II) neutral complexes, exhibited almost similar molecular structures, which can be described as discrete mononuclear complexes of the general chemical formula 
$\left[\mathrm{FeL}_{2}(\mathrm{NCS})_{2}\right]$, where two L chelating ligands $\left(\mathrm{L}=\mathrm{dpea}(\mathbf{1})\right.$, dppa $\left(\mathbf{2}\right.$ and $\left.\left.\mathbf{2}^{\prime}\right)\right)$ stand in the cis-positions, and the two thiocyanato- $\mathrm{kN}$ ligands complete the octahedral environment of the Fe(II) metal ions in the two remaining cis-positions. For complex 1, the thermal variation of the $\chi m T$ product showed a complete gradual HS-LS spin crossover transition at $T_{1 / 2}=229 \mathrm{~K}$, while the two polymorphs I-[Fe(dppa $\left.)_{2}(\mathrm{NCS})_{2}\right](2)$ and II-[Fe(dppa $\left.)_{2}(\mathrm{NCS})_{2}\right]\left(2^{\prime}\right)$ displayed similar magnetic behaviors at lower transition temperatures $\left(T_{1 / 2}=211 \mathrm{~K}\right.$ for $2 ; 212 \mathrm{~K}$ for $\left.2^{\prime}\right)$, which is in good agreement with the strong structural changes of the $\mathrm{FeN}_{6}$ coordination spheres derived from the structural characterizations at room temperature and at $170 \mathrm{~K}$. A careful examination of the intermolecular contacts in the three complexes did not reveal any significant intermolecular interaction, suggesting the absence of significant cooperative effects which agrees well the gradual behaviors shown by the magnetic data. However, complex 1 showed a transition temperature $(229 \mathrm{~K})$ clearly different from those observed for the two polymorph complexes $\left(T_{1 / 2}=211 \mathrm{~K}\right.$ for $2 ; 212 \mathrm{~K}$ for $\left.2^{\prime}\right)$. Such difference was ascribed to the more pronounced linearity of the Fe-N-CS angles observed for the two polymorphs 2 and 2'.

Supplementary Materials: The following are available online at http:/ / www.mdpi.com/2073-4352/8/11/401/s1. Crystallographic data for the structure reported in this paper were deposited in the Cambridge Crystallographic Data Centre as supplementary publication Nos. CCDC 1866637 (170 K) and 1866638 (296 K) for 1; 1866639 (170 K) and $1866640(296 \mathrm{~K})$ for 2; $1866641(170 \mathrm{~K})$ and $1866642(296 \mathrm{~K})$ for $\mathbf{2}^{\prime}$. A copy of the data can be obtained free of charge on application to CCDC, 12 Union Road, Cambridge CB21EZ, UK (Fax: +44-1223-336-033; E-Mail: deposit@ccdc.cam.ac.uk).

Author Contributions: The manuscript was written through contributions of all authors. T.H. and E.C. synthesized the ligand and the metal complexes and made the first experimental characterizations. M.M. and S.Y. analyzed the crystal data of the three complexes at room temperature $(296 \mathrm{~K})$ and at 170 K. D.P. performed and analyzed the magnetic studies as a function of temperature. S.T. supervised the experimental work and wrote the manuscript to which all the authors contributed.

Funding: This research was funded by the Université de Brest, the Centre National de la Recherche Scientifique (CNRS), Agence Nationale de la Recherche (project BISTA-MAT: ANR-12-BS07-0030-01) and by the Polish National Science Centre (Project 2016/22/E/ST5/00055).

Acknowledgments: The authors acknowledge the CNRS (Centre National de la Recherche Scientifique), the "Université de Brest", and the "Agence Nationale de la Recherche" (ANR project BISTA-MAT: ANR-12-BS07-0030-01). DP gratefully acknowledges the financial support of the Polish National Science Centre within the Sonata Bis 6 (2016/22/E/ST5/00055) research project.

Conflicts of Interest: The authors declare no conflict of interest.

\section{References}

1. Halcrow, M.A. (Ed.) Spin-Crossover Materials, Properties and Applications; John Wiley \& Sons Ltd.: Oxford, UK, 2013.

2. Gütlich, P.; Goodwin, H.A. (Eds.) Topics in Current Chemistry; Springer: Berlin/Heidelberg, Germany; New York, NY, USA, 2004; pp. 233-235.

3. Pittala, N.; Thétiot, F.; Triki, S.; Boukheddaden, K.; Chastanet, G.; Marchivie, M. Cooperative 1D Triazole-Based Spin Crossover Fe ${ }^{\mathrm{II}}$ Material with Exceptional Mechanical Resilience. Chem. Mater. 2017, 29 , 490-494. [CrossRef]

4. Pittala, N.; Thétiot, T.; Charles, C.; Triki, S.; Boukheddaden, K.; Chastanet, G.; Marchivie, M. An unprecedented trinuclear $\mathrm{Fe}^{\mathrm{II}}$ triazole-based complex exhibiting a concerted and complete sharp spin transition above room temperature. Chem. Commun. 2017, 53, 8356-8359. [CrossRef] [PubMed]

5. Milin, E.; Patinec, V.; Triki, S.; Bendeif, E.-E.; Pillet, S.; Marchivie, M.; Chastanet, G.; Boukheddaden, K. Elastic Frustration Triggering Photoinduced Hidden Hysteresis and Multistability in a Two-Dimensional Photoswitchable Hofmann-Like Spin-Crossover Metal-Organic Framework. Inorg. Chem. 2016, 55, 11652-11661. [CrossRef] [PubMed]

6. Shatruk, M.; Phan, H.; Chrisostomo, B.A.; Suleimenova, A. Symmetry-breaking structural phase transitions in spin crossover complexes. Coord. Chem. Rev. 2015, 289-290, 62-73. [CrossRef]

7. Atmani, C.; El Hajj, F.; Benmansour, S.; Marchivie, M.; Triki, S.; Conan, F.; Patinec, V.; Handel, H.; Dupouy, G.; Gómez-García, C.J. Guidelines to design new spin crossover materials. Coord. Chem. Rev. 2010, 254, 1559-1569. [CrossRef] 
8. Coronado, E.; Galán-Mascarós, J.R.; Monrabal-Capilla, M.; García-Martínez, J.; Pardo-Ibáñez, P. Bistable Spin-Crossover Nanoparticles Showing Magnetic Thermal Hysteresis near Room Temperature. Adv. Mater. 2007, 19, 1359-1361. [CrossRef]

9. Shalabaeva, V.; Ridier, K.; Rat, S.; Manrique-Juarez, M.D.; Salmon, L.; Séguy, I.; Rotaru, A.; Molnár, G.; Bousseksou, A. Room temperature current modulation in large area electronic junctions of spin crossover thin films. Appl. Phys. Lett. 2018, 112, 013301. [CrossRef]

10. Senthil Kumar, K.; Ruben, M. Emerging trends in spin crossover (SCO) based functional materials and devices. Coord. Chem. Rev. 2017, 346, 176-205. [CrossRef]

11. Dugay, J.; Giménez-Marqués, M.; Kozlova, T.; Zandbergen, H.W.; Coronado, E.; van der Zant, H.S.J. Spin switching in electronic devices based on 2D assemblies of spin-crossover nanoparticles. Adv. Mater. 2015, 27, 1288-1293. [CrossRef] [PubMed]

12. El Hajj, F.; Sebki, G.; Patinec, V.; Marchivie, M.; Triki, S.; Handel, H.; Yefsah, S.; Tripier, R.; Gomez-García, C.-J.; Coronado, E. Macrocycle-Based Spin-Crossover Materials. Inorg. Chem. 2009, 48, 10416-10423. [CrossRef] [PubMed]

13. Baadji, N.; Sanvito, S. Giant resistance change across the phase transition in spin-crossover molecules. Phys. Rev. Lett. 2012, 108, 217201. [CrossRef] [PubMed]

14. Prins, F.; Monrabal-Capilla, M.; Osorio, E.A.; Coronado, E.; van der Zant, H.S.J. Room-temperature electrical addressing of a bistable spin-crossover molecular system. Adv. Mater. 2011, 23, 1545-1549. [CrossRef] [PubMed]

15. Setifi, F.; Benmansour, S.; Marchivie, M.; Dupouy, G.; Triki, S.; Sala-Pala, J.; Salaün, J.-Y.; Gómez-García, C.J.; Pillet, S.; Lecomte, C.; et al. Magnetic bistability and thermochromism in molecular $\mathrm{Cu}^{\mathrm{II}}$ chain. Inorg. Chem. 2009, 48, 1269-1271. [CrossRef] [PubMed]

16. Arroyave, A.; Lennartson, A.; Dragulescu-Andrasi, A.; Pedersen, K.S.; Piligkos, S.; Stoian, S.A.; Greer, S.M.; Pak, C.; Hietsoi, O.; Phan, H.; et al. Spin Crossover in Fe(II) Complexes with $\mathrm{N}_{4} \mathrm{~S}_{2}$ Coordination. Inorg. Chem. 2016, 55, 5904-5913. [CrossRef] [PubMed]

17. Matar, S.F.; Guionneau, P.; Guillaume Chastanet, G. Multiscale Experimental and Theoretical Investigations of Spin Crossover Fe $\mathrm{II}^{\mathrm{II}}$ Complexes: Examples of [Fe(phen $\left.)_{2}(\mathrm{NCS})_{2}\right]$ and [Fe(PM-BiA $\left.)_{2}(\mathrm{NCS})_{2}\right]$. Int. J. Mol. Sci. 2015, 16, 4007-4027. [CrossRef] [PubMed]

18. Gaspar, A.B.; Agustí, G.; Martínez, V.; Muñoz, M.C.; Levchenko, G.; Real, J.A. Spin crossover behaviour in the iron(II)-2,2-dipyridilamine system: Synthesis, X-ray structure and magnetic studies. Inorg. Chim. Acta 2005, 358, 4089-4094. [CrossRef]

19. Gaspar, A.B.; Ksenofontov, V.; Real, J.A.; Gütlich, P. Coexistence of spin-crossover and antiferromagnetic coupling phenomena in the novel dinuclear Fe(II) complex $\left[\mathrm{Fe}(\mathrm{dpa})(\mathrm{NCS})_{2}\right]_{2}$ bpym. Chem. Phys. Lett. 2003, 373, 385-391. [CrossRef]

20. Nebbali, K.; Mekuimemba, C.D.; Charles, C.; Yefsah, S.; Chastanet, G.; Mota, A.J.; Colacio, E.; Triki, S. One-dimensional Thiocyanato-Bridged Fe(II) Spin Crossover Cooperative Polymer With Unusual FeN $\mathrm{N}_{5}$ Coordination Sphere. Inorg. Chem. 2018, 57, 12338-12346. [CrossRef] [PubMed]

21. Paulsen, H.; Grünsteudel, H.; Meyer-Klaucke, W.; Gerdan, M.; Grünsteudel, H.F.; Chumakov, A.I.; Rüffer, R.; Winkler, H.; Toftlund, H.; Trautwein, A.X. The spin-crossover complex [Fe(tpa)(NCS) $\left.)_{2}\right]$. Eur. Phys. J. 2001, B23, 463-472. [CrossRef]

22. Bonnet, S.; Siegler, M.A.; Sanchez Costa, J.; Molnar, G.; Bousseksou, A.; Spek, A.L.; Gamez, P.; Reedijk, J. A two-step spin crossover mononuclear iron(II) complex with a [HS-LS-LS] intermediate phase. Chem. Commun. 2008, 5619-5621. [CrossRef] [PubMed]

23. Milin, E.; Belaïd, S.; Patinec, V.; Triki, S.; Chastanet, G.; Marchivie, M. Dinuclear Spin-Crossover Complexes Based on Tetradentate and Bridging Cyanocarbanion Ligands. Inorg. Chem. 2016, 55, 9038-9046. [CrossRef] [PubMed]

24. Dupouy, G.; Marchivie, M.; Triki, S.; Sala-Pala, J.; Salaün, C.J.Y.; Gómez-García, C.J.; Guionneau, P. The Key Role of the Intermolecular $\pi-\pi$ Interactions on the Presence of Spin Crossover in Neutral $\left[\mathrm{Fe}(\mathrm{abpt}){ }_{2} \mathrm{~A}_{2}\right]$ Complexes (A = terminal monoanion N-ligand). Inorg. Chem. 2008, 47, 8921-8931. [CrossRef] [PubMed]

25. Dupouy, G.; Marchivie, M.; Triki, S.; Sala-Pala, J.; Gomez-Garcia, C.J.; Pillet, S.; Lecomte, C.; Létard, J.-F. Photoinduced HS state in the first spin-crossover chain containing a cyanocarbanion as bridging ligand. Chem. Commun. 2009, 23, 3404-3406. [CrossRef] [PubMed] 
26. Benmansour, S.; Atmani, C.; Setifi, F.; Triki, S.; Marchivie, M.; Gómez-García, C.J. Polynitrile anions as ligands: From magnetic polymeric architectures to spin crossover materials. Coord. Chem. Rev. 2010, 254, 1468-1478. [CrossRef]

27. Dupouy, G.; Triki, S.; Marchivie, M.; Cosquer, N.; Gómez-García, C.J.; Pillet, S.; Bendeif, E.-E.; Lecomte, C.; Asthana, S.; Létard, J.-F. Cyanocarbanion-based spin crossover materials: Photocrystallographic and photomagnetic studies of a new iron(II) neutral chain. Inorg. Chem. 2010, 49, 9358-9368. [CrossRef] [PubMed]

28. Yamasaki, M.; Ishida, T. First Iron(II) Spin-crossover Complex with an $\mathrm{N}_{5} \mathrm{~S}$ Coordination Sphere. Chem. Lett. 2015, 44, 920-921. [CrossRef]

29. Mekuimemba, C.D.; Conan, F.; Mota, A.J.; Palacios, M.A.; Colacio, E.; Triki, S. On the Magnetic Coupling and Spin Crossover Behavior in Complexes Containing the Head-to-Tail [Fe $\left.{ }_{2}(\mu-S C N)_{2}\right]$ Bridging Unit: A Magnetostructural Experimental and Theoretical Study. Inorg. Chem. 2018, 57, 2184-2192. [CrossRef] [PubMed]

30. Park, J.G.; Jeon, I.-R.; Harris, T.D. Electronic Effects of Ligand Substitution on Spin Crossover in a Series of Diiminoquinonoid-Bridged $\mathrm{Fe}_{2}{ }_{2}$ Complexes. Inorg. Chem. 2015, 54, 359-369. [CrossRef] [PubMed]

31. Wei, R.-J.; Li, B.; Tao, J.; Huang, R.-B.; Zheng, L.-S.; Zheng, Z. Making Spin-Crossover Crystals by Successive Polymorphic Transformations. Inorg. Chem. 2011, 50, 1170-1172. [CrossRef] [PubMed]

32. Wei, R.-J.; Huo, Q.; Tao, J.; Huang, R.-B.; Zheng, L.-S. Spin-Crossover Fe ${ }_{4}{ }_{4}$ Squares: Two-Step Complete Spin Transition and Reversible Single-Crystal-to-Single-Crystal Transformation. Angew. Chem. Int. Ed. 2011, 50, 8940-8943. [CrossRef] [PubMed]

33. Li, B.; Wei, R.-J.; Tao, J.; Huang, R.-B.; Zheng, L.-S.; Zheng, Z. Solvent-Induced Transformation of Single Crystals of a Spin-Crossover (SCO) Compound to Single Crystals with Two Distinct SCO Centers. J. Am. Chem. Soc. 2010, 132, 1558-1566. [CrossRef] [PubMed]

34. Scott, H.S.; Ross, T.M.; Phonsri, W.; Moubaraki, B.; Chastanet, G.; Létard, J.-F.; Batten, S.R.; Murray, K.S. Discrete $\mathrm{Fe}^{\mathrm{II}}$ Spin-Crossover Complexes of 2,2'-Dipyridylamino-Substituted s-Triazine Ligands with Phenoxo, Cyanophenoxo and Dibenzylamino Functionalities. Eur. J. Inorg. Chem. 2015, 763-777. [CrossRef]

35. Scott, H.S.; Moubaraki, B.; Paradis, N.; Chastanet, G.; Létard, J.-F.; Batten, S.R.; Murray, K.S. 2,2'-Dipyridylamino-based ligands with substituted alkyl chain groups and their mononuclear-M(II) spin crossover complexes. J. Mater. Chem. C 2015, 3, 7845-7857. [CrossRef]

36. Nassirinia, N.; Amani, S.; Teat, S.J.; Roubeau, O.; Gamez, P. Enhancement of spin-crossover cooperativity mediated by lone pair-p interactions and halogen bonding. Chem. Commun. 2014, 50, 1003-1005. [CrossRef] [PubMed]

37. Wannarit, N.; Roubeau, O.; Youngme, S.; Teatd, S.J.; Gamez, P. Influence of supramolecular bonding contacts on the spin crossover behaviour of iron(II) complexes from 2,2'-dipyridylamino/s-triazine ligands. Dalton Trans. 2013, 42, 7120-7130. [CrossRef] [PubMed]

38. Wannarit, N.; Roubeau, O.; Youngme, S.; Gamez, P. Subtlety of the Spin-Crossover Phenomenon Observed with Dipyridylamino-Substituted Triazine Ligands. Eur. J. Inorg. Chem. 2013, 730-737. [CrossRef]

39. Scott, H.S.; Ross, T.M.; Batten, S.R.; Gass, I.A.; Moubaraki, B.; Neville, S.M.; Murray, K.S. Iron(II) Mononuclear Materials Containing Functionalised Dipyridylamino-Substituted Triazine Ligands: Structure, Magnetism and Spin Crossover. Aust. J. Chem. 2012, 65, 874-882. [CrossRef]

40. Ross, T.M.; Moubaraki, B.; Neville, S.M.; Batten, S.R.; Murray, K.S. Polymorphism and spin crossover in mononuclear $\mathrm{Fe}^{\mathrm{II}}$ species containing new dipyridylamino-substituted s-triazine ligands. Dalton Trans. 2012, 41, 1512-1523. [CrossRef] [PubMed]

41. Ross, T.M.; Moubaraki, B.; Wallwork, K.S.; Batten, S.R.; Murray, K.S. A temperature-dependent order-disorder and crystallographic phase transition in a $0 \mathrm{D} \mathrm{Fe}^{\mathrm{II}}$ spin crossover compound and its non-spin crossover $\mathrm{Co}^{\mathrm{II}}$ isomorph. Dalton Trans. 2011, 40, 10147-10155. [CrossRef] [PubMed]

42. Quesada, M.; Monrabal, M.; Aromí, G.; de la Peña-O'Shea, V.A.; Gich, M.; Molins, E.; Roubeau, O.; Teat, S.J.; MacLean, E.J.; Gamez, P.; et al. Spin transition in a triazine-based Fe(II) complex: Variable-temperature structural, thermal, magnetic and spectroscopic studies. J. Mater. Chem. 2006, 16, 2669-2676. [CrossRef]

43. Amoore, J.J.M.; Kepert, C.J.; Cashion, J.D.; Moubaraki, B.; Neville, S.M.; Murray, K.S. Structural and Magnetic Resolution of a Two-Step Full Spin-Crossover Transition in a Dinuclear Iron(II) Pyridyl-Bridged Compound. Chem. Eur. J. 2006, 12, 8220-8227. [CrossRef] [PubMed] 
44. Quesada, M.; de Hoog, P.; Gamez, P.; Roubeau, O.; Aromí, G.; Donnadieu, B.; Massera, C.; Lutz, M.; Spek, A.L.; Reedijk, J. Coordination Dependence of Magnetic Properties within a Family of Related $\left[\mathrm{Fe}^{\mathrm{II}}{ }_{2}\right]$ Complexes of a Triazine-Based Ligand. Eur. J. Inorg. Chem. 2006, 2006, 1353-1361. [CrossRef]

45. Neville, S.M.; Leita, B.A.; Offermann, D.A.; Duriska, M.B.; Moubaraki, B.; Chapman, K.W.; Halder, G.J.; Murray, K.S. Spin-Crossover Studies on a Series of 1D Chain and Dinuclear Iron(II) Triazine-Dipyridylamine Compounds. Eur. J. Inorg. Chem. 2007, 1073-1085. [CrossRef]

46. Scott, H.S.; Ross, T.M.; Chilton, N.F.; Gass, I.A.; Moubaraki, B.; Chastanet, G.; Paradis, N.; Létard, J.-F.; Vignesh, K.R.; Rajaraman, G.; et al. Crown-linked dipyridylamino-triazine ligands and their spin-crossover iron(II) derivatives: Magnetism, photomagnetism and cooperativity. Dalton Trans. 2013, 42, 16494-16509. [CrossRef] [PubMed]

47. Ross, T.M.; Moubaraki, B.; Batten, S.R.; Murray, K.S. Spin crossover in polymeric and heterometallic $\mathrm{Fe}^{\mathrm{II}}$ species containing polytopic dipyridylamino-substituted-triazine ligands. Dalton Trans. 2012, 41, 2571-2581. [CrossRef] [PubMed]

48. Ross, T.M.; Moubaraki, B.; Turner, D.R.; Halder, G.J.; Chastanet, G.; Neville, S.M.; Cashion, J.D.; Létard, J.-F.; Batten, S.R.; Murray, K.S. Spin Crossover and Solvate Effects in $1 \mathrm{D} \mathrm{Fe}{ }^{\mathrm{II}}$ Chain Compounds Containing Bis(dipyridylamine)-Linked Triazine Ligands. Eur. J. Inorg. Chem. 2011, 1395-1417. [CrossRef]

49. Neville, S.M.; Leita, B.A.; Halder, G.J.; Kepert, C.J.; Moubaraki, B.; Létard, J.-F.; Murray, K.S. Understanding the Two-Step Spin-Transition Phenomenon in Iron(II) 1D Chain Materials. Chem. Eur. J. 2008, 14, 10123-10133. [CrossRef] [PubMed]

50. Quesada, M.; dela Peña-O'Shea, V.A.; Aromí, G.; Geremia, S.; Massera, C.; Roubeau, O.; Gamez, P.; Reedijk, J. A Molecule-Based Nanoporous Material Showing Tuneable Spin-Crossover Behavior near Room Temperature. Adv. Mater. 2007, 19, 1397-1402. [CrossRef]

51. Rauterkus, M.J.; Fakih, S.; Mock, C.; Puscasu, I.; Krebs, B. Cisplatin analogues with 2,2-dipyridylamine ligands and their reactions with DNA model nucleobases. Inorg. Chim. Acta 2003, 350, 355-365. [CrossRef]

52. Guionneau, P.; Marchivie, M.; Bravic, G.; Létard, J.-F.; Chasseau, D. Structural Aspects of Spin Crossover. Example of the $\left[\mathrm{Fe}^{\mathrm{II}} \mathrm{L}_{n}(\mathrm{NCS})_{2}\right]$ Complexes. Top. Curr. Chem. 2004, 234, 97-128.

53. Farrugia, L.J. ORTEP-3 for Windows-A version of ORTEP-III with a Graphical User Interface (GUI). J. Appl. Cryst. 1997, 30, 565. [CrossRef]

54. Spackman, M.A.; Byrom, P.G. A novel definition of a molecule in a crystal. Chem. Phys. Lett. 1997, 267, 215-220. [CrossRef]

55. Spackman, M.A.; McKinnon, J.J. Fingerprinting intermolecular interactions in molecular crystals. CrystEngComm 2002, 4, 378-392. [CrossRef]

56. Turner, M.J.; McKinnon, J.J.; Wolff, S.K.; Grimwood, D.J.; Spackman, P.R.; Jayatilaka, D.; Spackman, M.A. CrystalExplorer17; University of Western Australia: Crawley, Australia, 2017.

57. Marchivie, M.; Guionneau, P.; Létard, J.-F.; Chasseau, D. Towards direct correlation between spin crossover and structural properties in iron II complexes. Acta Cryst. B 2003, 59, 479-486. [CrossRef]

58. Oxford Diffraction. Xcalibur CCD/RED CrysAlis Software System; Oxford Diffraction Ltd.: Abingdon, UK, 2006.

59. Altomare, A.; Burla, M.C.; Camalli, M.; Cascarano, C.; Giacovazzo, C.; Guagliardi, A.; Moliterni, A.G.G.; Polidori, G.; Spagna, R. SIR97: A new tool for crystal structure determination and refinement. J. Appl. Cryst. 1999, 32, 115-119. [CrossRef]

60. Sheldrick, G. Crystal structure refinement with SHELXL. Acta Cryst. C 2015, 71, 3-8. [CrossRef] [PubMed]

(C) 2018 by the authors. Licensee MDPI, Basel, Switzerland. This article is an open access article distributed under the terms and conditions of the Creative Commons Attribution (CC BY) license (http://creativecommons.org/licenses/by/4.0/). 